

Research Article

\title{
Control of the buoyancy of Microcystis aeruginosa via colony formation induced by regulating extracellular polysaccharides and cationic ions
}

\author{
Kai Wei ${ }^{1}$ (D) Sanghyeob Jung ${ }^{2} \cdot$ Yoshimasa Amano ${ }^{3,4} \cdot$ Motoi Machida $^{3,4}$
}

Received: 29 July 2019 / Accepted: 5 November 2019 / Published online: 8 November 2019

(c) Springer Nature Switzerland AG 2019

\begin{abstract}
It is well recognized that gas vesicles influence the buoyancy of Microcystis and control the migration in the water column. Some of Microcystis strains do not have gas vesicles, so these strains cannot obtain buoyancy from them. In this study, we used two types of Microcystis strains such as the non-gas vesicle synthesizing strain M. aeruginosa UTEX-2061 and the gas vesicle synthesizing strain M. aeruginosa NIES-843 in the buoyancy control experiments of $M$. aeruginosa. By inducing colony formation and calculating the relative buoyancy rate of each strain, it was proven that the colony formation was strictly related to the buoyancy of both Microcystis strains. M. aeruginosa NIES-843 possessing gas vesicles could obtain buoyancy under the lower concentration of calcium and magnesium than M. aeruginosa UTEX-2061 possessing no gas vesicles. With the addition of the extracellular polysaccharides (EPS) extracted from Microcystis blooms into the culture medium, M. aeruginosa NIES-843 and UTEX-2061 could present higher buoyancy at the lowest concentrations of calcium and magnesium. It was suggested that EPS combined with the divalent metal cations such as calcium and magnesium made Microcystis form colony effectively. Calcium and magnesium ions enhanced the ability of colony formation of Microcystis and had a significant influence on buoyancy.
\end{abstract}

Keywords Buoyancy · Colony formation · Extracellular polysaccharides · Cationic ions · Microcystis

\section{Introduction}

In recent years, with deepening lake eutrophication and the excessive discharge of industrial effluent, cyanobacterial blooms mainly composed of the genus Microcystis (Microcystis blooms) in eutrophic lakes have become more frequent [39]. The outbreak of Microcystis blooms causes a series of environmental problems such as the production of cyanotoxins (e.g., microcystin), which could affect the survival of animals and plants in water, and people who drink the affected water could suffer from serious diseases such as liver cancer [23].
It is well known that Microcystis blooms appear in eutrophic lakes and accumulate at the water surface during the summer, and as the water temperature drops, they sink to the bottom of the lake and survive as "seeds" until the next year [33]. Then, they recruit from sediment and accumulate again at the surface water, repeating floating and sinking as an annual cycle [34]. There are two main reasons that Microcystis can float and settle in water. The first reason is that Microcystis has a particular structure called gas vesicle and can obtain buoyancy and float to the water surface by synthesizing gas vesicles [36]. The second reason is that photosynthetic production such as carbohydrates causes an increase in cellular weight [33].

$\triangle$ KaiWei, weikai@chiba-u.jp; Sanghyeob Jung, microcrumer@chiba-u.jp; Yoshimasa Amano, amanoy@faculty.chiba-u.jp; Motoi Machida, machida@faculty.chiba-u.jp | ${ }^{1}$ Graduate School of Science and Engineering, Chiba University, 1-33, Yayoi-cho, Inage-ku, Chiba 263-8522, Japan. ${ }^{2}$ Faculty of Engineering, Chiba University, 1-33, Yayoi-cho, Inage-ku, Chiba 263-8522, Japan. ${ }^{3}$ Graduate School of Engineering, Chiba University, 1-33, Yayoi-cho, Inage-ku, Chiba 263-8522, Japan. ${ }^{4}$ Safety and Health Organization, Chiba University, 1-33, Yayoi-cho, Inage-ku, Chiba 263-8522, Japan. 
As a result, Microcystis sinks into the bottom of the water. When the respiration reduces the carbohydrate content at night, the weight is lost leading Microcystis to float to the water surface.

It was reported that the cyanobacterium Nostoc muscorum could synthesize gas vesicles in the cell [35] and the gas vesicle structure was found in the cyanobacterium Microcystis aeruginosa [40]. It is also indicated from [36] that the gas vesicle affected the buoyancy of $M$. aeruginos $a$ and that the gas vesicle is composed of proteins. The buoyancy of $M$. aeruginosa is also influenced by solution pH. Microcystis sp. FACHB 928 cultured in a high solution $\mathrm{pH}(\mathrm{pH} 10)$ was easy to float compared to the solution at $\mathrm{pH} 8.5$, and by using a transmission electron microscope (TEM), it was found that the gas vesicle was more synthesized under high $\mathrm{pH}$ condition [11]. In the latest study, the genes from Bacillus megaterium pNL29 and Anabaena flosaquae $\mathrm{pET} 28 \mathrm{a}$ were added to the Escherichia coli gene, and E. coli could synthesize gas vesicles exhibiting buoyancy in a test tube [5]. In a study of [41], M. aeruginosa NIES-843 floated in a test tube had gas vesicles, and none of the gas vesicles were detected for $M$. aeruginosa at the bottom of the test tube. These findings indicate that the gas vesicle plays a significant role in the cyanobacterial buoyancy, and the gas vesicle is generally considered to give the motility in Microcystis that obtains buoyancy [36].

In addition to gas vesicles, the synthesis of carbohydrates by cyanobacteria through photosynthesis is also considered to be one of the driving forces controlling the cyanobacterial buoyancy [36]. The representative carbohydrate in cyanobacteria is called extracellular polysaccharides (EPS), and EPS has been proven to be strongly related to the colony formation of $M$. aeruginosa [19]. EPS was first discovered in the microbial cells, releasing copious extracellular slime secretions which formed a capsulelike structure around the cell [12]. EPS capsule is thought to be closely related to the cell adhesion and movement in the water column [7]. By ionic attractive force, two carboxyl groups can bind to divalent metal cations to achieve a relatively stable composition $[9,44,48]$. In the recent reports of $[28,29]$, a mixture of divalent metal ions and EPS was added to the culture medium of unicellular $M$. aeruginosa, and $M$. aeruginosa could form a larger colony. $M$. aeruginosa could also absorb iron and cadmium ion in water to form colonies [1, 4], and this absorption property can be considered as an effective adsorbent for toxic ions in water. The addition of microcystin to the culture medium also caused the colony formation of Microcystis sp. FACHB1027, and with the higher concentration of microcystin, Microcystis could form the larger colony [10].

Consequently, the colony formation of Microcystis would be related to the secretion of algal toxins [10]. Some zooplankton may prey on cyanobacteria in the water, and in order to avoid predation by predators, cyanobacteria synthesize EPS and form a larger colony $[15,45]$.

In fact, under natural conditions, some of Microcystis strains do not have gas vesicles, so these strains cannot obtain buoyancy from them [27]. The theory that gas vesicles control the buoyancy of Microcystis cannot explain the movement of all Microcystis strains in water. Thus, in this study, we used the non-gas vesicle synthesizing strain M. aeruginosa UTEX-2061 and the gas vesicle synthesizing strain M. aeruginosa NIES-843 $[18,26,27]$ in the buoyancy control experiments. By inducing colony formation using EPS extracted from Microcystis blooms and calculating the relative buoyancy rate of each strain, it was proven that the colony formation was strictly related to the buoyancy of both Microcystis strains.

\section{Materials and methods}

\subsection{Collection of Microcystis blooms}

Lake Senba $\left(36^{\circ} 22^{\prime} \mathrm{N}, 140^{\circ} 27^{\prime} \mathrm{E}\right)$, located in Ibaraki Prefecture, Japan, has the storage volume and the average depth of $365,000 \mathrm{~m}^{3}$ and $1.0 \mathrm{~m}$, respectively, and was the site for the collection of Microcystis blooms. The water quality such as chemical oxygen demand (COD) in Lake Senba was improved from 28.5 to $10 \mathrm{mg} / \mathrm{L}$ (as the mean annual value) due to lake water purification project conducted in 1986. However, because of recent water quality degradation, the mean COD and total phosphorus (TP) concentration values in 2017 were 15.0 and $0.16 \mathrm{mg} / \mathrm{L}$, respectively, which still exceeded the target values of environmental standards related to water pollution (COD: $\leq 8.0 \mathrm{mg} / \mathrm{L}$, TP: $\leq 0.10 \mathrm{mg} / \mathrm{L}$ ) in Lake Senba [21].

We collected a surface sample at the points of station 1 ([St. 1]) (Fig. 1) on the south side of Lake Senba. Sampling was carried out at a depth of $5 \mathrm{~cm}$ from the water surface. The samples taken from Lake Senba were brought to the laboratory and kept at $4{ }^{\circ} \mathrm{C}$ in the dark condition until use.

\subsection{M. aeruginosa culture}

M. aeruginosa (strain: NIES-843) was obtained from the National Institute for Environmental Studies (NIES), Tsukuba, Japan. M. aeruginosa NIES-843 possesses the ability of colony formation. This strain was cultured in $300 \mathrm{~mL}$ of modified MA medium [16] in 1 L Erlenmeyer flasks at $25^{\circ} \mathrm{C}$ for 14 or 28 days under continuous illumination of 4,500 lx. The MA medium consisted of a mixture of bicine $(500 \mathrm{mg}), \mathrm{Ca}\left(\mathrm{NO}_{3}\right)_{2} \cdot 4 \mathrm{H}_{2} \mathrm{O}(50 \mathrm{mg}), \mathrm{KNO}_{3}(100 \mathrm{mg})$, $\mathrm{NaNO}_{3}(50 \mathrm{mg}), \mathrm{Na}_{2} \mathrm{SO}_{4}(40 \mathrm{mg}), \mathrm{MgCl}_{2} \cdot 6 \mathrm{H}_{2} \mathrm{O}(50 \mathrm{mg})$, $\beta-\mathrm{Na}_{2}$ glycerophosphate $(100 \mathrm{mg})$ and a metal mixed solution ( $1 \mathrm{~mL}$ containing $1 \mathrm{mg}$ of $\mathrm{Na}_{2}$ EDTA, $0.1 \mathrm{mg}$ of 
Fig. 1 Sampling site of Lake Senba

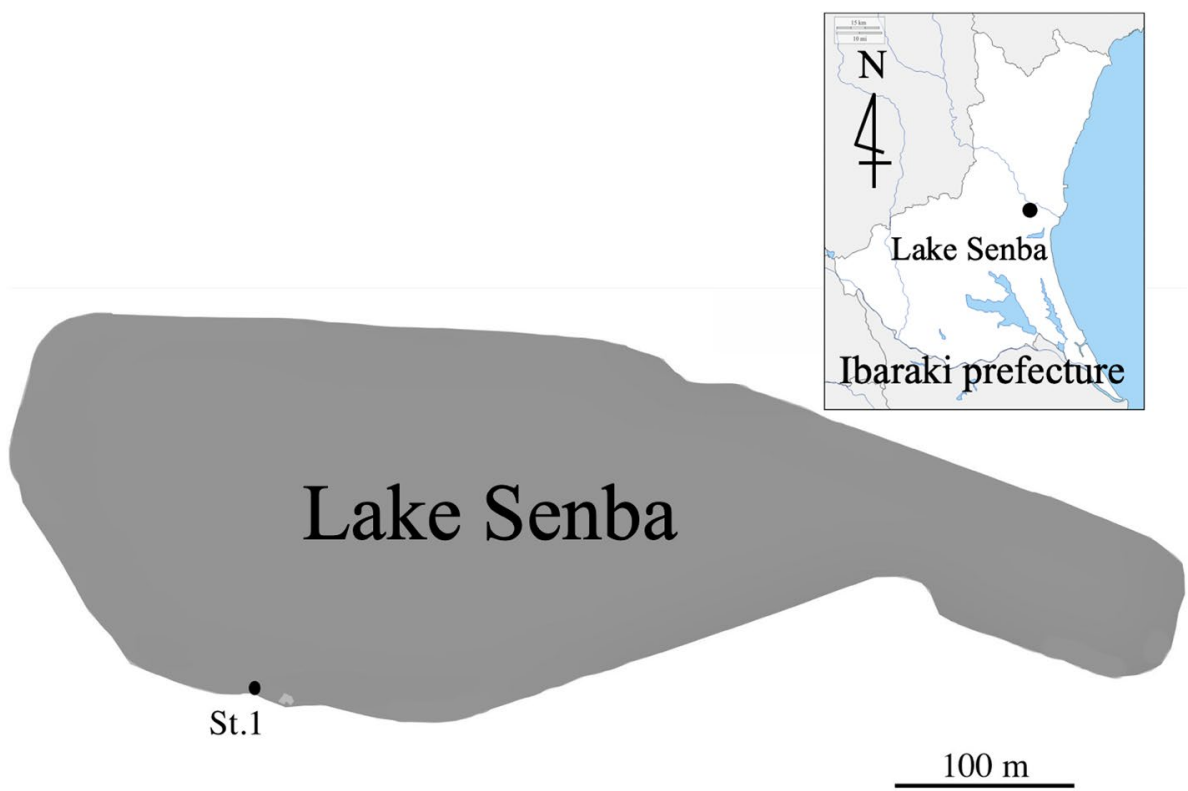

$\mathrm{FeCl}_{3} \cdot 6 \mathrm{H}_{2} \mathrm{O}, 1 \mathrm{mg}$ of $\mathrm{MnCl}_{3} \cdot 4 \mathrm{H}_{2} \mathrm{O}, 0.1 \mathrm{mg}$ of $\mathrm{ZnCl}_{2}, 1 \mathrm{mg}$ of $\mathrm{CoCl}_{2} \cdot 6 \mathrm{H}_{2} \mathrm{O}, 0.16 \mathrm{mg}$ of $\mathrm{Na}_{2} \mathrm{MoO}_{4} \cdot 2 \mathrm{H}_{2} \mathrm{O}$, and $4 \mathrm{mg}$ of $\mathrm{H}_{3} \mathrm{BO}_{3}$ in $200 \mathrm{~mL}$ of distilled water) in $1 \mathrm{~L}$ of distilled water. The $\mathrm{pH}$ of the medium was adjusted to $8.6 \pm 0.1$ by a $\mathrm{D}-51 \mathrm{pH}$ meter (Horiba, Japan) using $0.5 \mathrm{M} \mathrm{NaOH}$.

M. aeruginosa (strain: UTEX-2061) was obtained from the Culture Collection of Algae, the University of Texas, USA. This strain was unicellular and never forms a colony. $M$. aeruginosa UTEX-2061 was cultured in $500 \mathrm{~mL}$ of modified Wright's Cryptophytes (WC) medium [14] in 1 L Erlenmeyer flasks at $25^{\circ} \mathrm{C}$ about 28 days under 4,500 Ix continuous illumination. The WC medium consisted of a mixture of $\mathrm{CaCl}_{2}$ (36.76 mg), $\mathrm{MgSO}_{4} \cdot 7 \mathrm{H}_{2} \mathrm{O}(36.97 \mathrm{mg}), \mathrm{NaHCO}_{3} \quad(12.60 \mathrm{mg})$, $\mathrm{K}_{2} \mathrm{HPO}_{4}(8.71 \mathrm{mg}), \mathrm{NaNO}_{3}(85.01 \mathrm{mg}), \mathrm{Na}_{2} \cdot \mathrm{EDTA}(4.36 \mathrm{mg})$, $\mathrm{FeCl}_{3} \cdot 6 \mathrm{H}_{2} \mathrm{O}(3.15 \mathrm{mg}), \mathrm{CuSO}_{4} \cdot 5 \mathrm{H}_{2} \mathrm{O}(0.01 \mathrm{mg}), \mathrm{ZnSO}_{4} \cdot 7 \mathrm{H}_{2} \mathrm{O}$ $(0.022 \mathrm{mg}), \mathrm{CoCl}_{2} \cdot 6 \mathrm{H}_{2} \mathrm{O}(0.01 \mathrm{mg}), \mathrm{MnCl}_{2} \cdot 4 \mathrm{H}_{2} \mathrm{O}(0.18 \mathrm{mg})$, $\mathrm{Na}_{2} \mathrm{MoO}_{4} \cdot 2 \mathrm{H}_{2} \mathrm{O}(0.006 \mathrm{mg}), \mathrm{H}_{3} \mathrm{BO}_{3}(1.0 \mathrm{mg})$, thiamin $\cdot \mathrm{HCl}$ $(0.1 \mathrm{mg})$, biotin $(0.005 \mathrm{mg}), B_{12}(0.005 \mathrm{mg}), 500 \mathrm{mg}$ tris(hydroxymethyl)-aminomethane (Tris buffer) in $1 \mathrm{~L}$ of distilled water. The $\mathrm{pH}$ of the medium was adjusted to $8.0 \pm 0.1$ by using $0.5 \mathrm{M} \mathrm{HCl}$. The MA and WC media used in the experiment were sterilized by autoclaving at $115 \mathrm{kPa}$ for $20 \mathrm{~min}$ at $121^{\circ} \mathrm{C}$. Inoculation and sampling of the culture medium were conducted in a clean bench to minimize bacterial contamination.

\subsection{Isolation of EPS and protocol of colony formation and buoyancy experiment of $M$. aeruginosa}

The EPS extraction protocol was referred to the study of $[2,22,28]$. Under the room temperature condition, $0.25 \mathrm{M}$ sodium hydroxide $(\mathrm{NaOH})$ and $2 \%(\mathrm{w} / \mathrm{v})$ ethylenediaminetetraacetic acid (EDTA) were added to the Microcystis blooms sample collected in Lake Senba. After stirring the solution well, the sample was allowed to leave for $1 \mathrm{~h}$ to dissolve the EPS from Microcystis cells. The sample solution was centrifuged at $3000 \mathrm{rpm}$ for $15 \mathrm{~min}$, and the supernatant was collected. The solution was further filtered with GF/C filter (Whatman, UK) to remove impurities, and ethanol was added into the filtrate to give a final concentration of $60 \%(\mathrm{v} / \mathrm{v})$, and it was allowed to precipitate the EPS in solution. Then, the mixture was stored in $-20^{\circ} \mathrm{C}$ for $16 \mathrm{~h}$. After that, the solution was centrifuged at $3000 \mathrm{rpm}$ for $15 \mathrm{~min}$, and the precipitate was collected. The collected sample was freeze-dried at $-0.1 \mathrm{MPa}$, and the dried sample was ground with a mortar and a pestle. The powdered EPS sample was stored in a desiccator until use.

M. aeruginosa NIES-843 and UTEX-2061 were precultured for 14 or 28 days. Although the cell density of $M$. aeruginosa remains stable after 14 days of culture $[30,47]$, the long-term cultivation for 28 days was also conducted because M. aeruginosa would synthesize large amounts of EPS. The use of these different aged $M$. aeruginosa leads to a deep understanding of the relationship between EPS and colony formation. After both strains were cultivated in each duration, $50 \mathrm{~mL}$ of the sample was poured into a graduated cylinder, and then calcium chloride $\left(\mathrm{CaCl}_{2}\right)$, magnesium chloride hexahydrate $\left(\mathrm{MgCl}_{2} \cdot 6 \mathrm{H}_{2} \mathrm{O}\right)$ and EPS were added to the graduated cylinder.

In the previous study, the influences of $\mathrm{Ca}^{2+}$ and $\mathrm{Mg}^{2+}$ concentrations on extracellular polysaccharides (EPS) content and colony formation of Microcystis were investigated [49]. It was also revealed that the addition of EPS and $\mathrm{Ca}^{2+}$ into the medium could lead $M$. aeruginosa to form colonies effectively when the EPS and $\mathrm{Ca}^{2+}$ concentrations 
were adjusted to 200 and $1000 \mathrm{mg} / \mathrm{L}$, respectively [28]. In the present study, the $\mathrm{Ca}^{2+}$ concentration $(\mathrm{w} / \mathrm{v})$ used in the buoyancy control experiments was controlled from 0 to $5000 \mathrm{mg} / \mathrm{L}$, while that of $\mathrm{Mg}^{2+}$ and EPS (w/v) was from $0-1500 \mathrm{mg} / \mathrm{L}$ to $14,000 \mathrm{mg} / \mathrm{L}$, respectively. Each concentration was gradually increased until the colony was formed and $M$. aeruginosa floated to the water surface. The control medium was also prepared without any additions of $\mathrm{Ca}^{2+}$, $\mathrm{Mg}^{2+}$ and EPS. Each prepared medium was cultivated at $25^{\circ} \mathrm{C}$ for $24 \mathrm{~h}$ at $4500 \mathrm{Ix}$. Each prepared medium was represented with components added. For example, the medium with the addition of $\mathrm{Ca}^{2+}, \mathrm{Mg}^{2+}$ and EPS was designated as " $\mathrm{Ca}^{2+}+\mathrm{Mg}^{2+}+\mathrm{EPS}^{\prime}$.

\subsection{Microscopic observation and relative buoyancy}

Microscope (Eclipse E100, Nikon, Japan) was used to observe the colony of $M$. aeruginosa. Because of longterm cultivation in the laboratory condition, M. aeruginosa UTEX-2061 was always observed as a single cell or twin cells. In this experiment, more than three cells in the aggregation were regarded as a colony. Optical microscopic images were taken with a digital camera system (AM-4023X, AnMo Electronics Corp, Taiwan).
In order to evaluate the buoyant ability of M. aeruginosa, the relative buoyancy in the graduated cylinder was calculated. When wild Microcystis obtained in Lake Senba was cultivated for $24 \mathrm{~h}$, they exhibited strong buoyancy floating to the upper $10 \mathrm{~mL}$ of the water surface as mentioned in detail below (Fig. 2). From these results, $M$. aeruginosa in the upper $10 \mathrm{~mL}$ layer $\left(V_{1}, \mathrm{~mL}\right)$ of the graduated cylinder was considered to present strong buoyancy and the cell density was recorded as $C_{1}$ (cells/ $\mathrm{mL})$. Similarly, M. aeruginosa in the lower $40 \mathrm{~mL}\left(V_{2}, \mathrm{~mL}\right)$ of the medium was thought to be weak buoyancy, and the density of this layer was recorded as $C_{2}$ (cells $/ \mathrm{mL}$ ). Then, the relative buoyancy (RB) was calculated from the cell density $\left(C_{1}, C_{2}\right)$ and the solution volume $\left(V_{1}, V_{2}\right)$ by the following equation.

$\mathrm{RB} \%=\frac{C_{1} V_{1}}{C_{1} V_{1}+C_{2} V_{2}} \times 100$

When $M$. aeruginosa was uniformly distributed in the graduated cylinder, the RB value was calculated to be $20 \%\left(\mathrm{RB}_{20}\right)$.
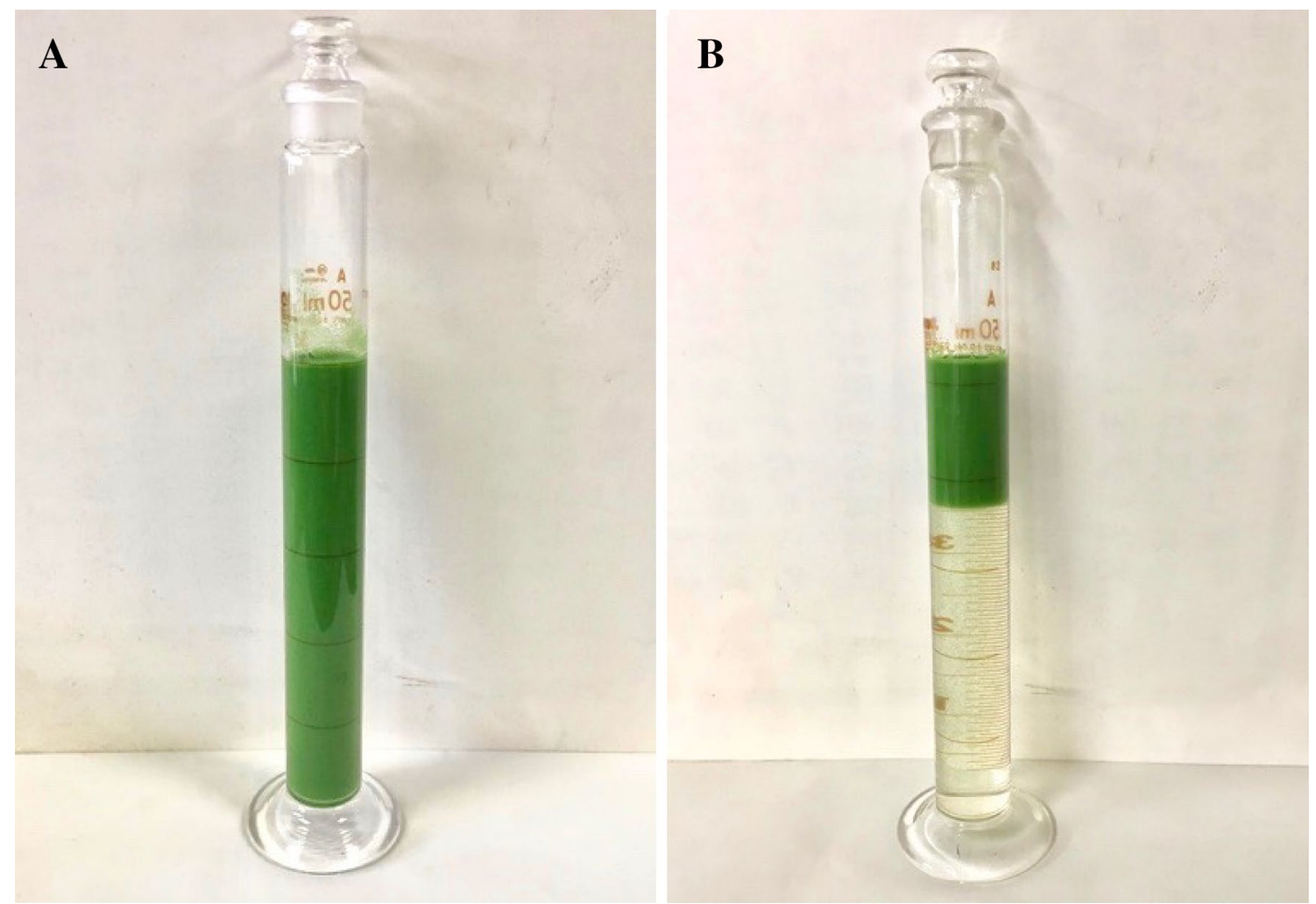

Fig. 2 Wild Microcystis strain cultured in a cylinder for $\mathbf{a} 0 \mathrm{~h}$ and $\mathbf{b} 24 \mathrm{~h}$ 


\section{Results}

\subsection{Buoyancy regulation of wild Microcystis strain}

The sample of wild Microcystis obtained from Lake Senba was cultivated for $24 \mathrm{~h}$ in the cylinder, and wild Microcystis before cultivation is depicted in Fig. 2a. After $24 \mathrm{~h}$, almost all Microcystis cells floated up to the water surface (Fig. 2b), indicating that wild Microcystis possesses strong buoyancy. An aliquot of Microcystis sample at the water surface was observed using a microscope. Wild Microcystis forms a large colony (Fig. 3), implying that the colony formation is closely related to the buoyancy. The RB value of wild Microcystis was calculated by Eq. (1), and the value was obtained to be ca. $90 \%$.

\subsection{Buoyancy regulation of $M$. aeruginosa NIES-843}

The change in the relative buoyancy of $M$. aeruginosa NIES-843 in the media with various calcium $\left(\mathrm{Ca}^{2+}\right)$, magnesium $\left(\mathrm{Mg}^{2+}\right)$ and EPS concentrations is shown in Fig. $4 a-f . \mathrm{Ca}^{2+}$ ion was added to M. aeruginosa NIES-843 medium cultured for 14 days, and when the amount of addition reached $150 \mathrm{mg} / \mathrm{L}, M$. aeruginosa NIES-843 presented the strong buoyancy and the RB value was close to $80 \%$. On the other hand, as for 28-day cultivation, when the $\mathrm{Ca}^{2+}$ concentration increased up to $75 \mathrm{mg} / \mathrm{L}$, the RB value exceeded $90 \%$ (Fig. 4a).

When $\mathrm{Mg}^{2+}$ was added to M. aeruginosa NIES-843 cultured for 14 days, the RB value increased from 20 to $40 \%$ at the $\mathrm{Mg}^{2+}$ concentration of $700 \mathrm{mg} / \mathrm{L}$ (Fig. 4B), whereas when $M$. aeruginosa NIES-843 was cultivated for 28 days,

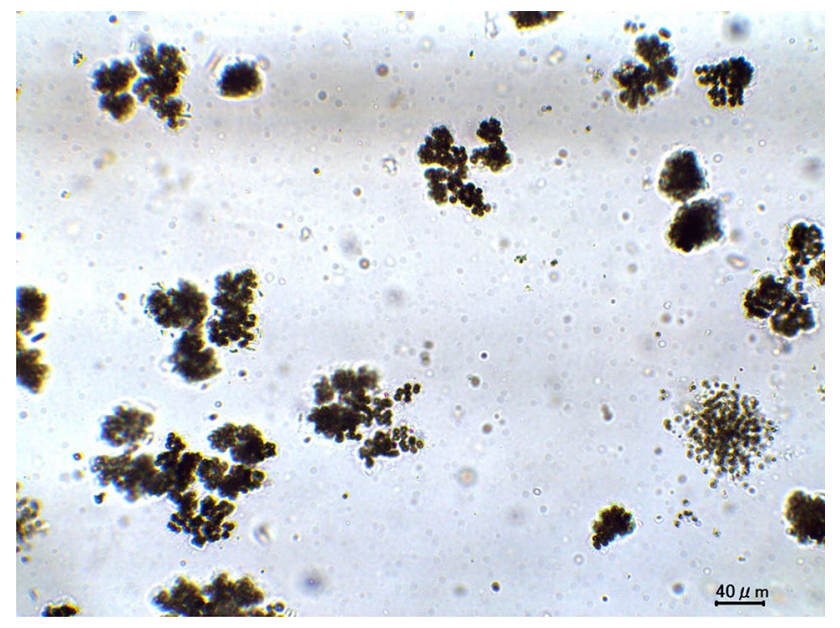

Fig. 3 Photographs of wild Microcystis cells located in the surface layers of a cylinder the RB value of $M$. aeruginosa NIES-843 was close to $80 \%$ and presented strong buoyancy at $250 \mathrm{mg} / \mathrm{L}$ or more.

The EPS addition into M. aeruginosa NIES-843 cultured for 14 days caused changes in the buoyancy. When the amount of added reached $16 \mathrm{~g} / \mathrm{L}$, the RB value of $M$. aeruginosa NIES-843 showed $80 \%$ and presented strong buoyancy (Fig. 4C). M. aeruginosa NIES-843 cultured for 28 days showed the same buoyancy when the addition of EPS reached $12 \mathrm{~g} / \mathrm{L}$. Although the addition of EPS alone could also make $M$. aeruginosa obtain buoyancy, a large amount of EPS addition would cause an increase in solution $\mathrm{pH}$ up to 12 (data not shown).

$\mathrm{Ca}^{2+}$ and $\mathrm{Mg}^{2+}$ ions were simultaneously added into the $M$. aeruginosa NIES-843 medium cultured for 14 days and 28 days with different proportions, and the magnesium and calcium mass ratio $\left(\mathrm{Mg}^{2}+\mathrm{Ca}^{2+}\right.$ ratio) of 3 exhibited the strongest buoyancy (Fig. 4d). From these results, the $\mathrm{Mg}^{2+}+\mathrm{Ca}^{2+}$ ratio was fixed to 3 in the experiments hereafter. $M$. aeruginosa NIES-843 cultivated for 14 days with the $\mathrm{Ca}^{2+}$ and $\mathrm{Mg}^{2+}$ concentrations of 70 and $210 \mathrm{mg} / \mathrm{L}$, respectively, indicated the strong buoyancy $(\mathrm{RB}=$ ca. $95 \%)$, while as for 28 days cultivation, the same high buoyancy $(R B=90 \%)$ was obtained when the $\mathrm{Ca}^{2+}$ and $\mathrm{Mg}^{2+}$ concentrations reached 60 and $180 \mathrm{mg} / \mathrm{L}$, respectively (Fig. 4e).

Microcystis aeruginosa NIES-843 cultured for 14 days and 28 days was added to a mixture of $\mathrm{Ca}^{2+}, \mathrm{Mg}^{2+}$ and EPS. Since the addition of EPS into the culture medium caused the rise of $\mathrm{pH}$, the amount of EPS in this experiment was controlled to $200 \mathrm{mg} / \mathrm{L}$. This condition gave the $\mathrm{pH}$ value in the solution to be about 9.2. M. aeruginosa cultivated for 14 days exhibited the strong buoyancy, indicating that the RB value was close to $90 \%$ at the $\mathrm{Ca}^{2+}$ and $\mathrm{Mg}^{2+}$ concentrations of 10 and $30 \mathrm{mg} / \mathrm{L}$ under constant EPS concentration (Fig. 4f). The 28-day cultivation resulted in the further increase in the buoyancy at the same concentrations $\left(\mathrm{Ca}^{2+}=10 \mathrm{mg} / \mathrm{L}\right.$, $\mathrm{Mg}^{2+}=30 \mathrm{mg} / \mathrm{L}$, EPS $=200 \mathrm{mg} / \mathrm{L}$ ), indicating almost $100 \%$ of the RB value. The medium with $\mathrm{Ca}^{2+}, \mathrm{Mg}^{2+}$ and EPS additions could make $M$. aeruginosa achieve much higher buoyancy than the combined addition of $\mathrm{Ca}^{2+}$ and $\mathrm{Mg}^{2+}$ (Fig. 4d, e).

\subsection{Microscopic observation of $M$. aeruginosa NIES-843}

Microscopic observation images of $M$. aeruginosa NIES843 in each medium were taken after the experiment to observe morphological changes and are shown in Fig. 5a-f. In the control medium, there were only small colonies aggregating four cells or five cells (Fig. 5a). The colony size in the media that were separately supplied with $\mathrm{Ca}^{2+}, \mathrm{Mg}^{2+}$ and EPS formed a bigger colony 
A

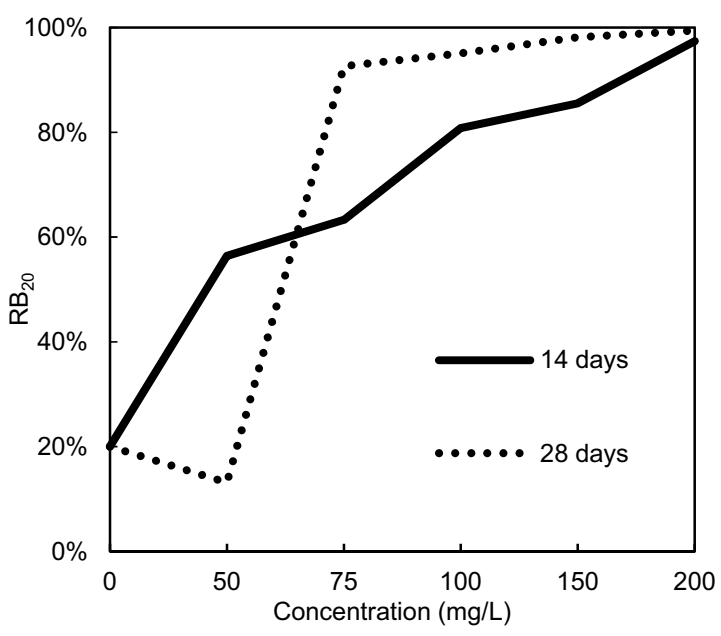

C

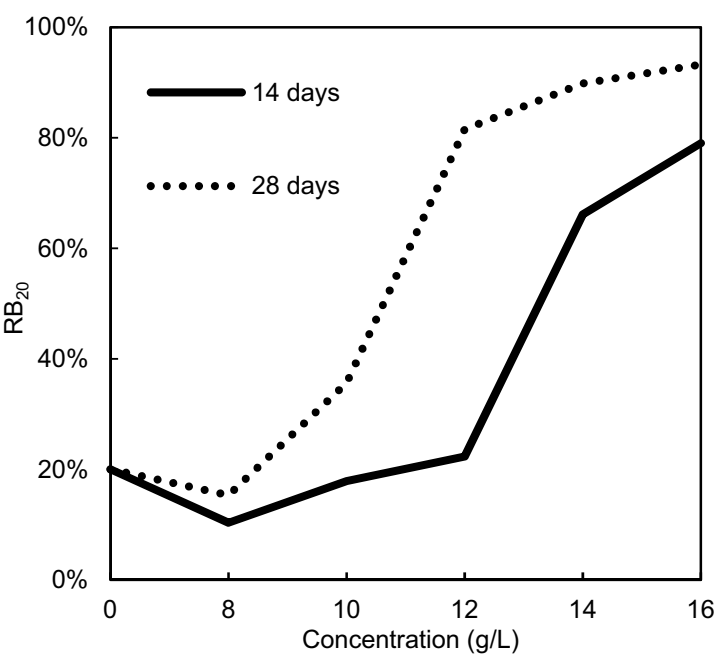

E

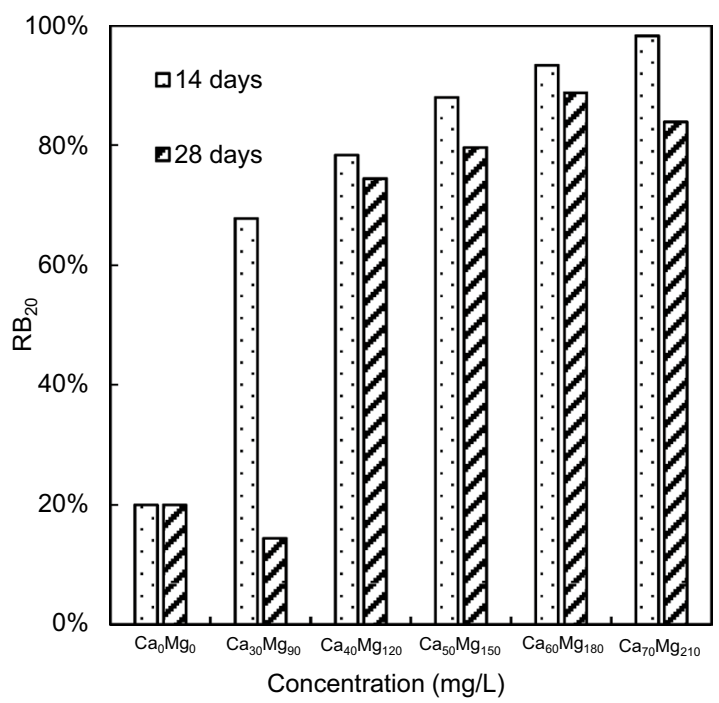

B

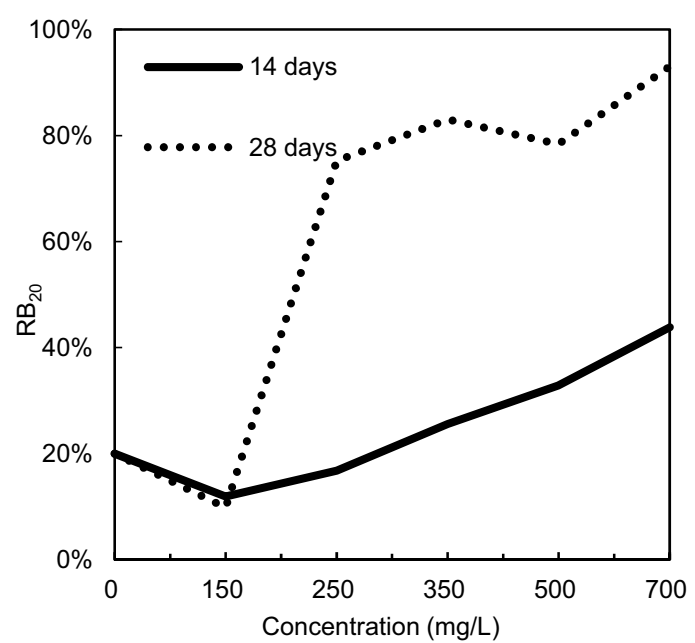

D

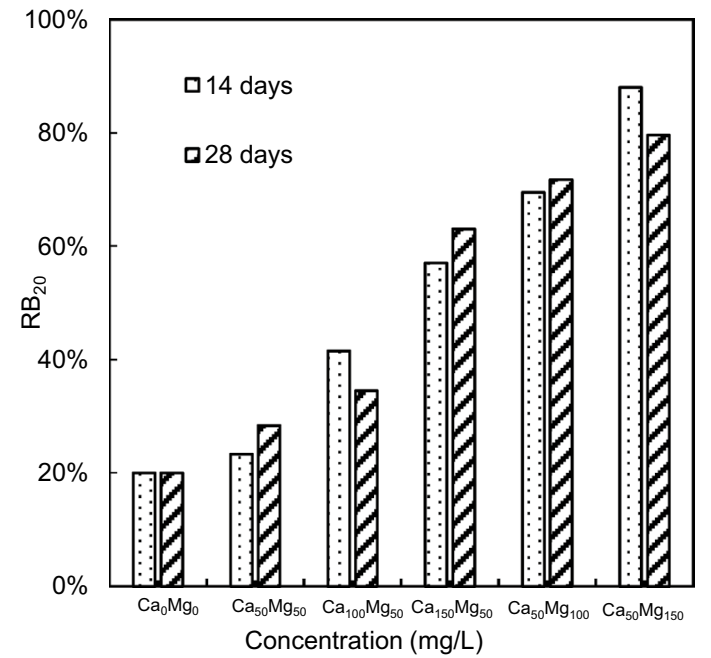

F

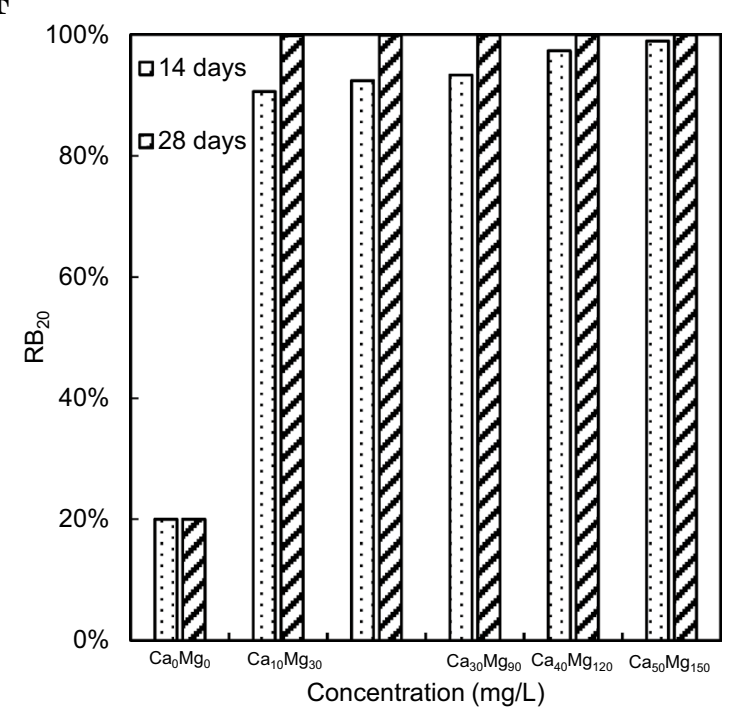


4 Fig. 4 Relative buoyancy of M. aeruginosa NIES-843 changed by the addition of $\mathbf{a ~ C a}{ }^{2+}, \mathbf{b ~ M g}{ }^{2+}, \mathbf{c}$ EPS, $\mathbf{d}$ different ratios of $\mathrm{Ca}^{2+}$ and $\mathrm{Mg}^{2}$, $\mathbf{e}^{+} \mathrm{Ca}^{2+}$ and $\mathrm{Mg}^{2+}, \mathbf{f} \mathrm{Ca}^{2+}, \mathrm{Mg}^{2+}$ and EPS

than the control medium (Fig. 5b-d). The medium with simultaneous addition of $\mathrm{Ca}^{2+}$ and $\mathrm{Mg}^{2+}$ obviously increased the size of colonies than the $\mathrm{Ca}^{2+}$ or $\mathrm{Mg}^{2+}$ added medium (Fig. 5e). The morphology of $M$. aeruginosa NIES-843 cells in the medium with the combination of $\mathrm{Ca}^{2+}, \mathrm{Mg}^{2+}$ and EPS showed a similar trend with the $\mathrm{Ca}^{2+}+\mathrm{Mg}^{2+}$ medium, but the colony size was largest among all media. The colonial morphology in the $\mathrm{Ca}^{2+}+\mathrm{Mg}^{2+}+$ EPS medium was similar to that of wild Microcystis (Fig. 3, Fig.5f).
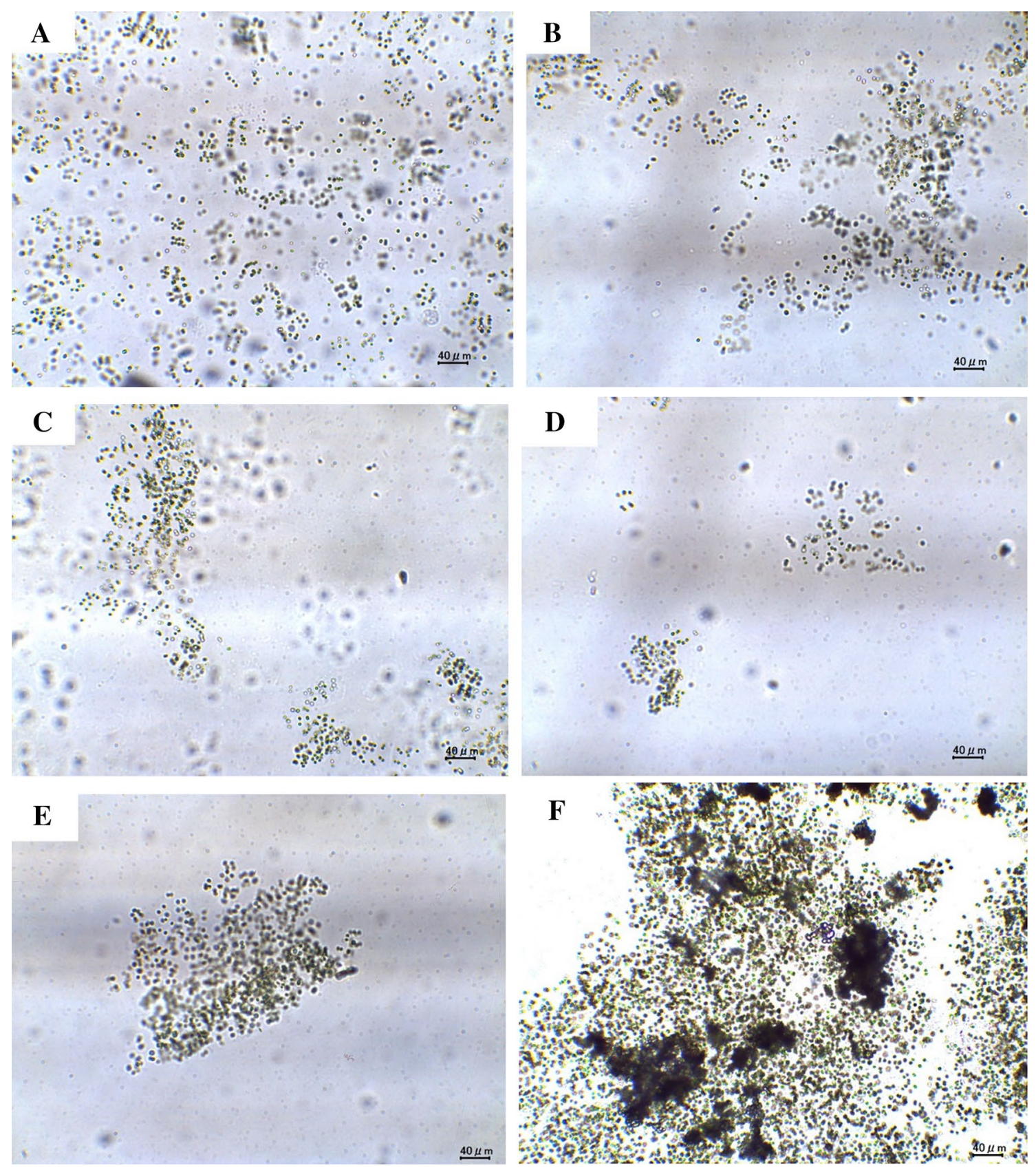

Fig. 5 Morphological observation of M. aeruginosa NIES-843 cells and colony presented in the surface layers of a cylinder: a control medium, b Ca ${ }^{2+} 100 \mathrm{mg} / \mathrm{L}, \mathbf{c ~} \mathrm{Mg}^{2+} 350 \mathrm{mg} / \mathrm{L}$, d EPS $12 \mathrm{~g} / \mathrm{L}$, e $\mathrm{Mg}^{2+}$

$150 \mathrm{mg} / \mathrm{L}$ and $\mathrm{Ca}^{2+} 50 \mathrm{mg} / \mathrm{L}, \mathrm{fmg}^{2+} 60 \mathrm{mg} / \mathrm{L}, \mathrm{Ca}^{2+} 20 \mathrm{mg} / \mathrm{L}$, and EPS $200 \mathrm{mg} / \mathrm{L}$ 
A

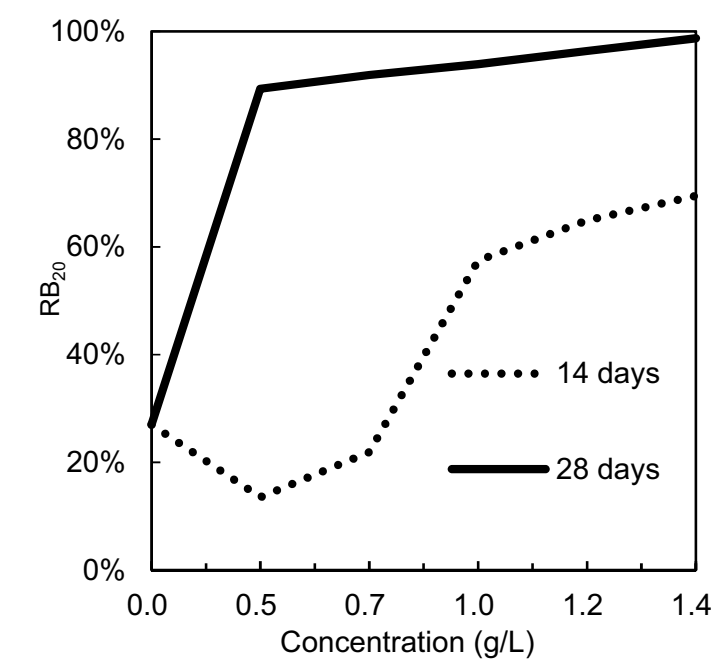

C

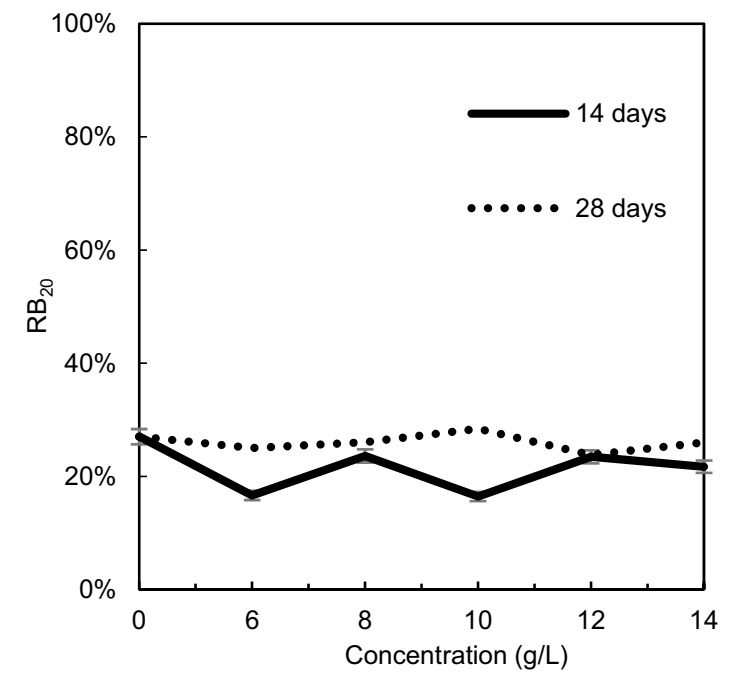

$\mathbf{E}$

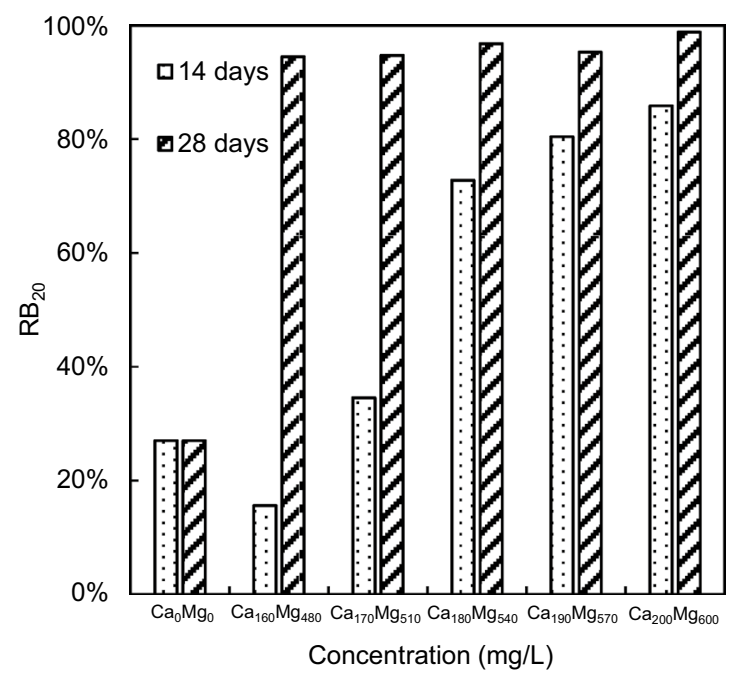

B

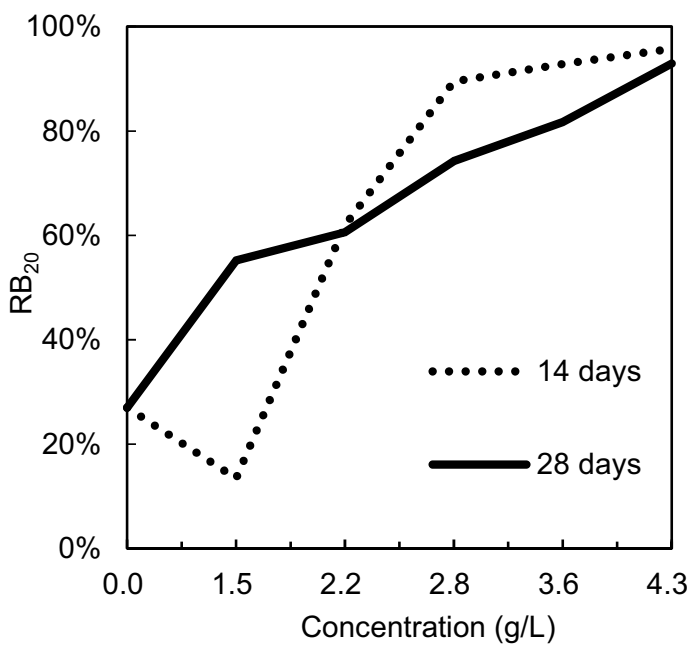

D

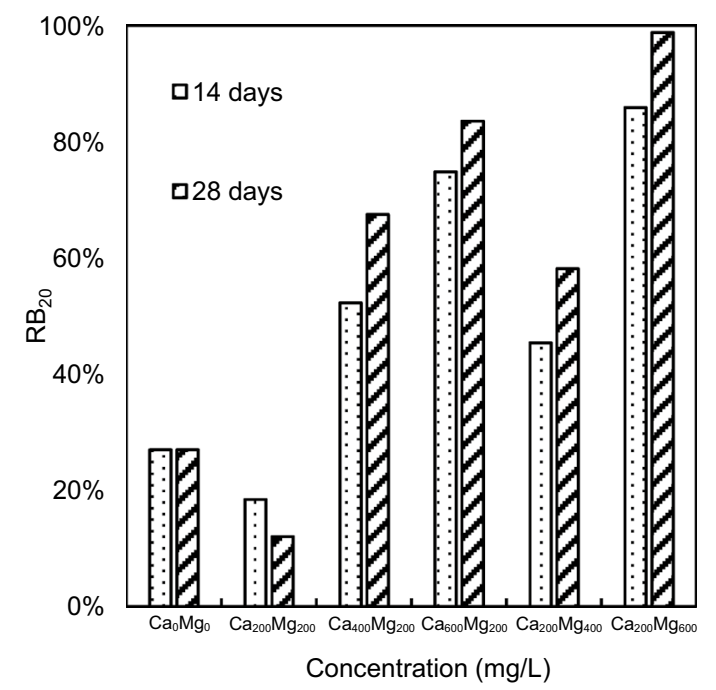

F

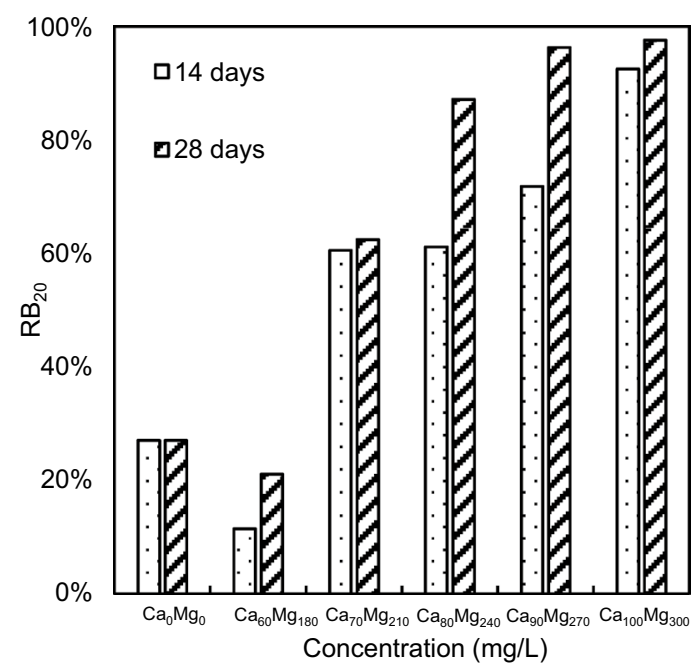


4Fig. 6 Relative buoyancy of M. aeruginosa UTEX-2061 changed by the addition of $\mathbf{a ~ C a}{ }^{2+}, \mathbf{b ~ M g}{ }^{2+}, \mathbf{c}$ EPS, $\mathbf{d}$ different ratios of $\mathrm{Ca}^{2+}$ and $\mathrm{Mg}^{2+}, \mathbf{e ~} \mathrm{Ca}^{2+}$ and $\mathrm{Mg}^{2+}, \mathbf{f} \mathrm{Ca}^{2+}, \mathrm{Mg}^{2+}$ and EPS

\subsection{Buoyancy regulation of $M$. aeruginosa UTEX-2061}

Changes in the relative buoyancy with adding $\mathrm{Ca}^{2+}$, $\mathrm{Mg}^{2+}$ and EPS into M. aeruginosa UTEX-2061 culture medium are shown in Fig. 6a-f. M. aeruginosa UTEX2061 cultivated for 14 days was added to the $\mathrm{Ca}^{2+}$ solution and when the amount of addition reached $3.6 \mathrm{~g} / \mathrm{L}$, the RB value was close to $90 \%$ and presented strong buoyancy (Fig. 6a). M. aeruginosa cultivated for 28 days grown with the $\mathrm{Ca}^{2+}$ concentration of $4.3 \mathrm{~g} / \mathrm{L}$ exceeded $90 \%$.

When M. aeruginosa UTEX-2061 was cultivated in the $\mathrm{Mg}^{2+}$ added medium for 14 days the RB value increased to $60 \%$ with the addition of $1.1 \mathrm{~g} / \mathrm{L}$. In the case of 28-day cultivation, the strong buoyancy with the RB value of $90 \%$ was observed at the $\mathrm{Mg}^{2+}$ concentration of $0.5 \mathrm{~g} / \mathrm{L}$ (Fig. 6b). Contrary to the cases of $\mathrm{Ca}^{2+}$ and $\mathrm{Mg}^{2+}$ ions, the single addition of EPS could not significantly change the buoyancy of M. aeruginosa UTEX-2061 (Fig. 6c).

Different proportions of $\mathrm{Ca}^{2+}$ and $\mathrm{Mg}^{2+}$ were added to the M. aeruginosa UTEX-2061 medium cultured for 14 days and 28 days, and it was found that M. aeruginosa presented the strongest buoyancy (Fig. $6 \mathrm{~d}$ ) at the $\mathrm{Mg}^{2} / \mathrm{Ca}^{2+}$ ratio of 3 as similar to the case of $M$. aeruginosa NIES-843. Based on the result, the ratio of $\mathrm{Mg}^{2+}$ and $\mathrm{Ca}^{2+}$ in the medium was maintained at 3. M. aeruginosa UTEX2061 cultured for 14 days was grown in the medium at $\mathrm{Ca}^{2+}$ of $200 \mathrm{mg} / \mathrm{L}$ and $\mathrm{Mg}^{2+}$ of $600 \mathrm{mg} / \mathrm{L}$ and represented the relative buoyancy of $80 \%$ (Fig. 6e). M. aeruginosa UTEX-2061 cultured for 28 days showed much higher buoyancy, indicating that the RB value was ca. $95 \%$ at $\mathrm{Ca}^{2+}=160 \mathrm{mg} / \mathrm{L}$ and $\mathrm{Mg}^{2+}=480 \mathrm{mg} / \mathrm{L}$.

Microcystis aeruginosa UTEX-2061 cultured for 14 and 28 days was added into the $\mathrm{Ca}^{2+}+\mathrm{Mg}^{2+}+$ EPS medium. The high buoyancy ( $\mathrm{RB}=90 \%$ ) of $M$. aeruginosa UTEX-2061 was observed at $\mathrm{Ca}^{2+}=100 \mathrm{mg} / \mathrm{L}$ and $\mathrm{Mg}^{2+}=300 \mathrm{mg} / \mathrm{L}$ for 14 days cultivation, and $\mathrm{Ca}^{2+}=80 \mathrm{mg} / \mathrm{L}$ and $\mathrm{Mg}^{2+}=240 \mathrm{mg} / \mathrm{L}$ for 28 days cultivation (Fig. $6 \mathrm{~F}$ ).

\subsection{Microscopic observation of $M$. aeruginosa UTEX-2061}

Microscopic observation for M. aeruginosa UTEX-2061 showed that, in the control medium, there were only single cells and twin cells, and no obvious $M$. aeruginosa UTEX-2061 colonies were observed (Fig. 7a). The medium that was added separately with $\mathrm{Ca}^{2+}, \mathrm{Mg}^{2+}$ and EPS formed a bigger colony than the control medium (Fig. 7a-d). The colony size in the $\mathrm{Ca}^{2+}+\mathrm{Mg}^{2+}$ medium was larger than separately added $\mathrm{Ca}^{2+}$ and $\mathrm{Mg}^{2+}$ medium (Fig. 7e). $M$. aeruginosa UTEX-2061 grown in the medium with the $\mathrm{Ca}^{2+}+\mathrm{Mg}^{2+}+$ EPS medium formed the largest colony, and the morphology of the colony was similar to that of wild Microcystis (Figs. 3, 7f).

\section{Discussion}

With the addition of $\mathrm{Ca}^{2+}, \mathrm{Mg}^{2+}$ and EPS into the medium, both $M$. aeruginosa strains formed colonies and obtained buoyancy, proving that the colony formation had a significant influence on the buoyancy of $M$. aeruginosa. It is found that $M$. aeruginosa NIES-843 could obtain the buoyancy at a lower concentration of $\mathrm{Ca}^{2+}$ and $\mathrm{Mg}^{2+}$ than $\mathrm{M}$. aeruginosa UTEX-2061 because the gas vesicle provides a portion of buoyancy. M. aeruginosa UTEX-2061 does not possess gas vesicles, but it can still exhibit the buoyancy by colony formation at a higher concentration of $\mathrm{Ca}^{2+}$ and $\mathrm{Mg}^{2+}$ concentrations. M. aeruginosa NIES-843 could also exhibit the buoyancy by adding a large amount of EPS, but the addition of EPS does not cause a significant change in buoyancy for M. aeruginosa UTEX-2061. It is assumed that $M$. aeruginosa NIES-843 possesses the ability of colony formation and thereby they would have higher amount of EPS around colonies and cells compared with M. aeruginosa UTEX-2061. The EPS added into the medium would interact with the EPS present around $M$. aeruginosa NIES843 cells, leading to the colony formation and promoting buoyancy. Dervaux et al. [8] reported that $M$. aeruginosa PCC7005 could float to the water surface by the addition of the extracted EPS into the culture medium. M. aeruginosa PCC7005 seemed to float by bubbles generated via photosynthesis. In the present study, we also confirmed the bubbles (Fig. 8), which would be one of the factors to cause the buoyancy of M. aeruginosa. Therefore, it was proved that the colony formation was strictly related to the buoyancy of Microcystis.

M. aeruginosa UTEX-2061 cultivated for 14 days exhibited the strong buoyancy, indicating that the relative buoyancy (RB) value was close to $90 \%$ at the $\mathrm{Ca}^{2+}$ and $\mathrm{Mg}^{2+}$ concentrations of 100 and $300 \mathrm{mg} / \mathrm{L}$ under EPS concentration of $200 \mathrm{mg} / \mathrm{L}$ (Fig. 6f). However, M. aeruginosa UTEX-2061 did not present strong buoyancy under the high concentration of $\mathrm{Ca}^{2+}$ ions $(1500 \mathrm{mg} / \mathrm{L})$ or $\mathrm{Mg}^{2+}$ ions $(700 \mathrm{mg} / \mathrm{L})$. Consequently, it is inferred that physical influence like a density rise of solution would not affect the buoyancy of M. aeruginosa UTEX-2061. The long-term cultivation of $M$. aeruginosa could synthesize large amounts of EPS in the medium [6]. In the present experiment, we found that 28 days cultivated $M$. aeruginosa was able to obtain buoyancy at lower concentrations of $\mathrm{Ca}^{2+}$ and $\mathrm{Mg}^{2+}$ than that 

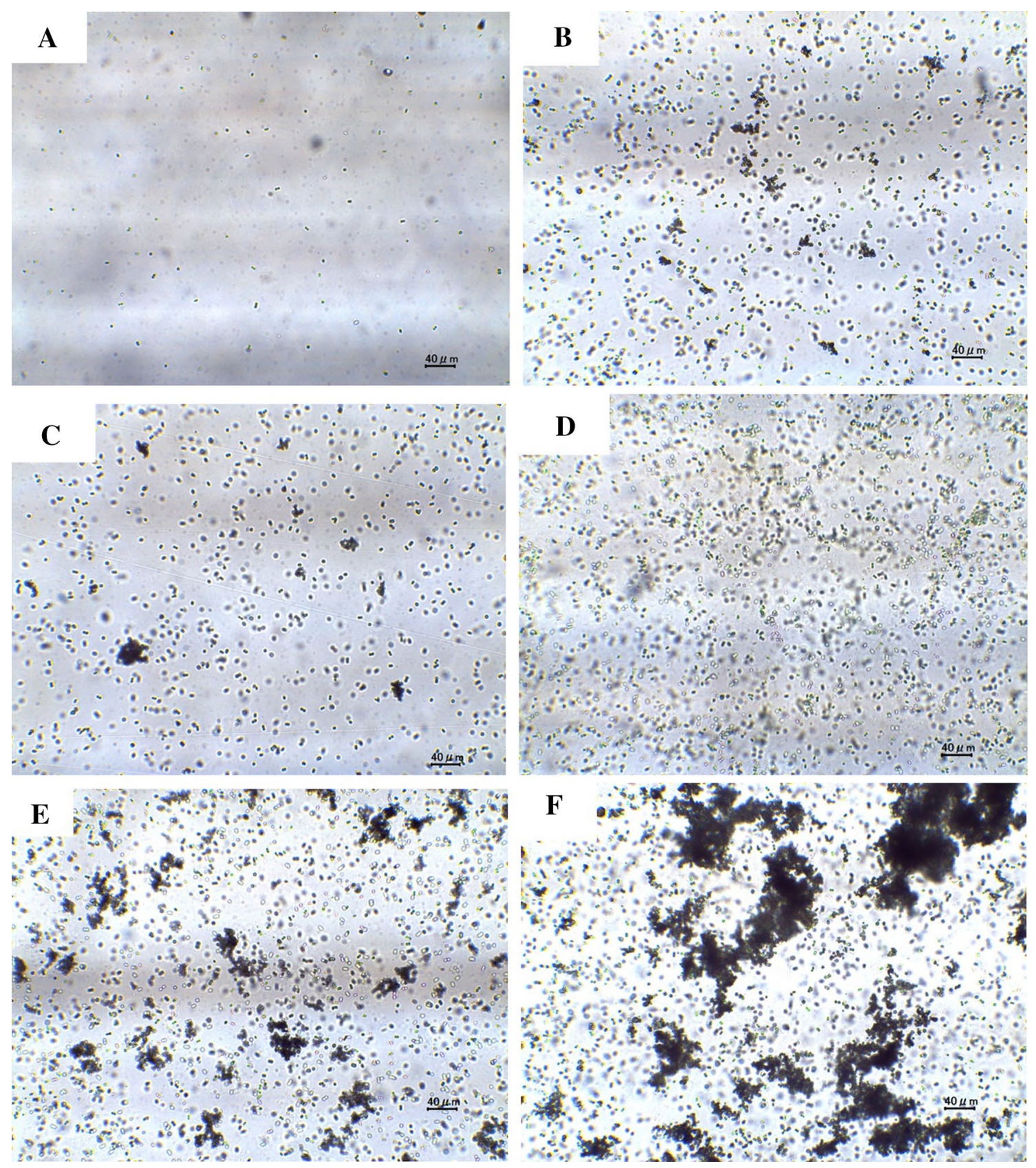

Fig. 7 Morphological observation of M. aeruginosa UTEX-2061 cells and colony located in the surface layers of the measuring cylinder: a control medium, b Ca ${ }^{2+} 3.6 \mathrm{~g} / \mathrm{L}, \mathbf{c ~ M g}^{2+} 0.5 \mathrm{~g} / \mathrm{L}$, d EPS $10 \mathrm{~g} / \mathrm{L}$, e

cultivated for 14 days because older M. aeruginosa would synthesize large amounts of EPS in the medium.

Because of synthesizing EPS and gas vesicle conducive to the maintenance of buoyancy, $M$. aeruginosa can exhibit strong buoyancy and remain stably on the water surface. It was reported that $M$. aeruginosa PCC6803 secreted less amount of EPS, which affected the buoyancy in the medium [17]. EPS can be divided into dissolved EPS and bound EPS. The bound EPS can be further fractionated
$\mathrm{Mg}^{2+} 480 \mathrm{mg} / \mathrm{L}$ and $\mathrm{Ca}^{2+} 160 \mathrm{mg} / \mathrm{L}, \mathrm{f} \mathrm{Mg}^{2+} 240 \mathrm{mg} / \mathrm{L}, \mathrm{Ca}^{2+} 80 \mathrm{mg} / \mathrm{L}$, and EPS $200 \mathrm{mg} / \mathrm{L}$

into loosely bound (LB-EPS) and tightly bound EPS (TBEPS) because it inherently has a dynamic double-layered structure [31]. Omori et al. [24] reported that TB-EPS induced colony formation more efficiently than EPS (not fractionated EPS, i.e., a mixture of dissolved, LB- and TBEPS), and more enormous amounts of carboxy groups were observed in the surface of TB-EPS. The carboxy groups can attract cationic ions via ionic attractive force and make cross-linking reaction between the carboxy 




Fig. 8 M. aeruginosa presented buoyancy in the surface layers of a cylinder and bubbles can be observed: a NIES-843, $\mathrm{Mg}^{2+} 60 \mathrm{mg} / \mathrm{L}$, $\mathrm{Ca}^{2+} 20 \mathrm{mg} / \mathrm{L}$, and EPS $200 \mathrm{mg} / \mathrm{L}$, b UTEX-2061, $\mathrm{Mg}^{2+} 240 \mathrm{mg} / \mathrm{L}$, $\mathrm{Ca}^{2+} 80 \mathrm{mg} / \mathrm{L}$, and EPS $200 \mathrm{mg} / \mathrm{L}$

groups and cationic ions. Therefore, the carboxy groups on TB-EPS would be contributed to colony formation, which causes buoyancy of M. aeruginosa. Xavier and Foster examined the relationship between oxygen concentration in water and EPS synthesis of M. aeruginosa, and revealed that under the low oxygen concentration, carbohydrate was mainly used to synthesize EPS. On the other hand, under the high oxygen concentration, $M$. aeruginosa primarily produces biomass and less amount of EPS via photosynthesis [43]. Therefore, M. aeruginosa presented at the bottom of the lake, where the oxygen concentration is low, can produce EPS to increase buoyancy. After floating from the bottom (low oxygen) to the water surface (high oxygen), photosynthesis mainly produces biomass and maintains the stability of the colony. The present study could further explain the phenomenon that wild Microcystis annually floats and sinks in water column. In summer, M. aeruginosa can synthesize a large amount of EPS by photosynthesis. In the winter when the photosynthesis is weakened, $M$. aeruginosa synthesizes little amount of EPS to maintain the stability of the colony and sinks into the bottom of water until the next summer.

Researchers focusing on the growth of $M$. aeruginosa do not attract attention to the concentration of $\mathrm{Ca}^{2+}$ and $\mathrm{Mg}^{2+}$ ions in lakes. In Lake Taihu, China, Microcystis blooms often occur in summer. M. aeruginosa in Lake Taihu can form a colony [20, 25, 42]. M. aeruginosa cultured under laboratory conditions is different from natural lakes. Without the addition of cationic ions and EPS, it is difficult to form $M$. aeruginosa colonies from unicellular and laboratory-cultured $M$. aeruginosa like wild colonies $[3,37]$. In recent years, the local government has taken measures to control the concentration of nitrogen and phosphorus, but the inhibition effect on M. aeruginosa is not satisfactory. It was reported that the addition of $\mathrm{Ca}^{2+}$ into the culture medium of $M$. aeruginosa FACHB 905 could promote the synthesis of EPS within $48 \mathrm{~h}$ [32]. $\mathrm{Ca}^{2+}$ promoted the growth rate of $M$. aeruginosa, and the buoyancy increased with the high $\mathrm{Ca}^{2+}$ concentration [38]. Ye et al. [46] reported that the $\mathrm{Ca}^{2+}$ concentration was about $58 \mathrm{mg} / \mathrm{L}$, and $\mathrm{Mg}^{2+}$ concentration was about $15 \mathrm{mg} / \mathrm{L}$ in the northern rivers of the Lake Taihu, where Microcystis blooms often occurred. The concentration of cationic ions in $\mathrm{MA}\left(\mathrm{Ca}^{2+}=8.5 \mathrm{mg} / \mathrm{L}, \mathrm{Mg}^{2+}=6 \mathrm{mg} / \mathrm{L}\right)$ and $\mathrm{WC}\left(\mathrm{Ca}^{2+}=10 \mathrm{mg} / \mathrm{L}, \mathrm{Mg}^{2+}=3.65 \mathrm{mg} / \mathrm{L}\right)$ medium is lower than those in Lake Taihu, China. It is reported that a high amount of calcium was concentrated in EPS, and approximately $200 \mathrm{mg} / \mathrm{L} \mathrm{Ca}^{2+}$ concentration was detected in colonies of wild strain M. aeruginosa [13]. In the present study, M. aeruginosa cultured under laboratory conditions cannot synthesize high amount of EPS and also $\mathrm{Ca}^{2+}$ and $\mathrm{Mg}^{2+}$ were not concentrated in EPS. This would require high $\mathrm{Ca}^{2+}$ and $\mathrm{Mg}^{2+}$ concentration in the medium to form $M$. aeruginosa colonies. Under the $\mathrm{Ca}^{2+}, \mathrm{Mg}^{2+}$ and EPS concentrations of 10,30 and $200 \mathrm{mg} / \mathrm{L}$, respectively, M. aeruginosa NIES-843 cultured for 28 days formed colonies and presented strong buoyancy, showing the RB value was close to $100 \%$. Therefore, the addition of $\mathrm{Ca}^{2+}, \mathrm{Mg}^{2+}$ ions and EPS into the medium promoted the ability of colony formation of Microcystis and had a significant influence on buoyancy. It suggests that the monitoring of the concentrations of these ions and substance in lakes, where Microcystis blooms occur frequently, is particularly essential. 


\section{Conclusions}

In this study, we used M. aeruginosa UTEX-2061 (without gas vesicles) and NIES-843 (with gas vesicles) in the buoyancy control experiments, and by inducing colony formation using EPS extracted from Microcystis blooms the change in the buoyancy of both $M$. aeruginosa strains were examined. The main conclusions were summarized as follows:

1. The colony formation of both M. aeruginosa UTEX-2061 and NIES-843 had a significant influence on their buoyancy.

2. With the addition of EPS into medium, M. aeruginosa presented higher buoyancy at the lowest concentrations of $\mathrm{Ca}^{2+}$ and $\mathrm{Mg}^{2+}$, suggesting that EPS combined with the divalent metals can make Microcystis form colony effectively.

3. The combination of $\mathrm{Ca}^{2+}$ and $\mathrm{Mg}^{2+}$ addition into medium could enhance the buoyancy of $M$. aeruginosa effectively compared with that with the addition of them separately.

Acknowledgements The authors would like to extend deep gratitude to Prof. Dr. Masu Hyuma, Center for Analytical Instrumentation Chiba University, for his fruitful and helpful discussions about the freezedried method.

Funding The present work was supported in part by JFE 21st Century Foundation and by JSPS KAKENHI Grant Number 18 K04404.

\section{Compliance with ethical standards}

Conflict of interest The authors declare that they have no competing interests.

\section{References}

1. Amano Y, Hosoi T, Machida M, Imazeki F (2013) Effects of extracellular polymeric substances (EPS) and iron ion on colony formation of unicellular Microcystis aeruginosa. J Jpn Soc Civ Eng 69(7):III_39-III_44

2. Amemiya Y, Nakayama O (1984) The chemical composition and metal adsorption capacity of the sheath materials isolated from Microcystis, Cyanobacteria. Jpn J Limnol 45:187-193

3. An Q, Li X, Wang S, Huang X, Jiang Y (2017) Effects of environmental factors on Microcystis aeruginosa colony formation and morphological characteristics in Three Gorges Reservoir (in Chinese). J Lake Sci 29(2):378-388

4. Bi X, Yan R, Li F, Dai W, Jiao K, Zhou Q, Liu Q (2016) Sequestration and distribution characteristics of Cd (II) by Microcystis aeruginosa and its role in colony formation. BioMed Res Int 2016:9837598
5. Bourdeau RW, Lee-Gosselin A, Lakshmanan A, Farhadi A, Kumar SR, Nety SP, Shapiro MG (2018) Acoustic reporter genes for noninvasive imaging of microorganisms in mammalian hosts. Nature 553(7686):86

6. De Brouwer JF, Stal LJ (2002) Daily fluctuations of exopolymers in cultures of the benthic diatoms Cylindrotheca closterium and Nitzschia sp. (Bacillariophyceae). J Phycol 38(3):464-472

7. Decho A (1990) Microbial exopolymer secretions in ocean environments: their role (s) in food webs and marine processes. Oceanogr Mar Biol Annu Rev 28(737153):9-16

8. Dervaux J, Mejean A, Brunet P (2015) Irreversible collective migration of cyanobacteria in eutrophic conditions. PLoS ONE 10(3):e0120906

9. Flemming $\mathrm{H}-\mathrm{C}$, Wingender $\mathrm{J}$ (2010) The biofilm matrix. Nat Rev Microbiol 8(9):623

10. Gan N, Xiao Y, Zhu L, Wu Z, Liu J, Hu C, Song L (2012) The role of microcystins in maintaining colonies of bloom-forming Microcystis spp. Environ Microbiol 14(3):730-742

11. Gao H, Zhu T, Xu M, Wang S, Xu X, Kong R (2016) pHdependent gas vesicle formation in Microcystis. FEBS Lett 590(18):3195-3201

12. Geesey G (1982) Microbial exopolymers: ecological and economic considerations. Am Soc Microbiol News 48:9-14

13. Goode C, Allen D (2011) Effect of calcium on moving-bed biofilm reactor biofilms. Water Environ Res 83(3):220-232

14. Guillard R, Lorenzen C (1972) Yellow-green algae with chlorophyllide c. J Phycol 8:10-14

15. Hahn MW, Lünsdorf H, Janke L (2004) Exopolymer production and microcolony formation by planktonic freshwater bacteria: defence against protistan grazing. Aquat Microb Ecol 35(3):297-308

16. Ichimura $T$ (1979) Media for freshwater cyanobacteria: methods in phycology. Kyouritsu Shuppan, Tokyo, pp 295-296

17. Jittawuttipoka T, Planchon M, Spalla O, Benzerara K, Guyot F, Cassier-Chauvat C, Chauvat F (2013) Multidisciplinary evidences that Synechocystis PCC6803 exopolysaccharides operate in cell sedimentation and protection against salt and metal stresses. PLoS ONE 8(2):e55564

18. Kaneko T, Nakajima N, Okamoto S, Suzuki I, Tanabe Y, Tamaoki M, Nakamura Y, Kasai F, Watanabe A, Kawashima K (2007) Complete genomic structure of the bloom-forming toxic cyanobacterium Microcystis aeruginosa NIES-843. DNA Res 14(6):247-256

19. Li L, Guo H, Shao C, Yu S, Yin D, Gao N, Lu N (2015) Effect of algal organic matter (AOM) extracted from Microcystis aeruginosa on photo-degradation of Diuron. Chem Eng J 281:265-271

20. Ma J, Brookes JD, Qin B, Paerl HW, Gao G, Wu P, Zhang W, Deng J, Zhu G, Zhang Y (2014) Environmental factors controlling colony formation in blooms of the cyanobacteria Microcystis spp. in Lake Taihu, China. Harmful Algae 31:136-142

21. Mito City (2018) Senba Lake official site (in Japanese). [Cited on 6 December 2018]. Available from: http://www.city.mito. lg.jp/001373/senbako/sbksuisitu/2811/p011958.html

22. Nishikawa S, Kuriyama M (1974) Nucleic acid as a component of mucilage in activated sludge. J Ferment Technol 52(5):335-338

23. Nishiwaki R, Ohta T, Nishiwaki S, Suganuma M, Kohyama K, Ishikawa T, Carmichael WW, Fujiki H (1992) Liver tumor promotion by the cyanobacterial cyclic peptide toxin microcystin-LR. J Cancer Res Clin Oncol 118(6):420-424

24. Omori K, Datta T, Amano Y, Machida M (2019) Effects of different types of extracellular polysaccharides isolated from cyanobacterial blooms on the colony formation of unicellular Microcystis aeruginosa. Environ Sci Pollut Res 26(4):3741-3750

25. Qin B, Yang G, Ma J, Wu T, Li W, Liu L, Deng J, Zhou J (2018) Spatiotemporal changes of cyanobacterial bloom in large shallow eutrophic Lake Taihu, China. Front Microbiol 9:451 
26. Rhee JS, Choi BS, Han J, Hwang SJ, Choi IY, Lee JS (2012) Draft genome database construction from four strains (NIES-298, FCY26, -27, and-28) of the cyanobacterium, Microcystis aeruginosa. J Microbiol Biotechnol 22(9):1208-1213

27. Rippka R, Deruelles J, Waterbury JB, Herdman M, Stanier RY (1979) Generic assignments, strain histories and properties of pure cultures of cyanobacteria. Microbiology 111(1):1-61

28. Sato M, Amano Y, Machida M, Imazeki F (2017) Colony formation of highly dispersed Microcystis aeruginosa by controlling extracellular polysaccharides and calcium ion concentrations in aquatic solution. Limnology 18(1):111-119

29. Sato M, Omori K, Datta T, Amano Y, Machida M (2017) Influence of extracellular polysaccharides and calcium ion on colony formation of unicellular Microcystis aeruginosa. Environ Eng Sci 34(3):149-157

30. Shen H, Niu Y, Xie P, Tao M, Yang X (2011) Morphological and physiological changes in Microcystis aeruginosa as a result of interactions with heterotrophic bacteria. Freshw Biol 56(6):1065-1080

31. Sheng G, Yu H, Li X (2010) Extracellular polymeric substances (EPS) of microbial aggregates in biological wastewater treatment systems: a review. Biotechnol Adv 28(6):882-894

32. Shi J, Wu Z, Song L (2013) Physiological and molecular responses to calcium supplementation in Microcystis aeruginosa (Cyanobacteria). N Z J Mar Freshw Res 47(1):51-61

33. Sigee D (2005) Freshwater microbiology: biodiversity and dynamic interactions of microorganisms in the aquatic environment. Wiley, London

34. Thomas R, Walsby A (1986) The effect of temperature on recovery of buoyancy by Microcystis. Microbiology 132(6):1665-1672

35. Waaland JR, Branton D (1969) Gas vacuole development in a blue-green alga. Science 163(3873):1339-1341

36. Walsby A (1994) Gas vesicles. Microbiol Rev 58(1):94-144

37. Wang Q, Pang W, Mao Y, Ge S, Yu H, Dai C, Zhao M (2000) Changes of extracellular polymeric substance (EPS) during Microcystis aeruginosa blooms at different levels of nutrients in a eutrophic microcosmic simulation device. Pol J Environ Stud 29:1-12

38. Wang Y-W, Zhao J, Li J-H, Li S-S, Zhang L-H, Wu M (2011) Effects of calcium levels on colonial aggregation and buoyancy of Microcystis aeruginosa. Curr Microbiol 62(2):679-683

39. Watson SB, Ridal J, Boyer GL (2008) Taste and odour and cyanobacterial toxins: impairment, prediction, and management in the Great Lakes. Can J Fish Aquat Sci 65(8):1779-1796
40. Weathers $P$, Jost M, Lamport D (1977) The gas vacuole membrane of Microcystis aeruginosa: a partial amino acid sequence. Arch Biochem 178(1):226-244

41. Wei K, Amano Y, Machida M, Asukabe H, Harada K (2018) Effects of light and potassium ion on buoyancy regulation with gas vesicle in a Cyanobacterium Microcystis aeruginosa NIES-843. Water Air Soil Pollut 229(11):352

42. Wu X, Kong $F(2009)$ Effects of light and wind speed on the vertical distribution of Microcystis aeruginosa colonies of different sizes during a summer bloom. Int Rev Hydrobiol 94(3):258-266

43. Xavier JB, Foster KR (2007) Cooperation and conflict in microbial biofilms. Proc Natl Acad Sci U S A 104(3):876-881

44. Xu H, Lv H, Liu X, Wang P, Jiang H (2016) Electrolyte cations binding with extracellular polymeric substances enhanced Microcystis aggregation: implication for Microcystis bloom formation in eutrophic freshwater lakes. Environ Sci Technol 50(17):9034-9043

45. Yang Z, Kong F (2012) Formation of large colonies: a defense mechanism of Microcystis aeruginosa under continuous grazing pressure by flagellate Ochromonas sp. J Limnol 71(1):e5

46. Ye H, Yuan X, Ge M, Li J, Sun H (2010) Water chemistry characteristics and controlling factors in the northern rivers in the Taihu Basin. Ecol Environ Sci 19(1):23-27

47. You J, Mallery K, Hong J, Hondzo M (2017) Temperature effects on growth and buoyancy of Microcystis aeruginosa. J Plankton Res 40(1):16-28

48. Zhang M, Kong F, Tan X, Yang Z, Cao H, Xing P (2007) Biochemical, morphological, and genetic variations in Microcystis aeruginosa due to colony disaggregation. World J Microbiol Biotechnol 23(5):663-670

49. Zhao L, Lu L, Li M, Xu Z, Zhu W (2011) Effects of Ca and Mg levels on colony formation and EPS content of cultured $M$. aeruginosa. Procedia Environ Sci 10:1452-1458

Publisher's Note Springer Nature remains neutral with regard to jurisdictional claims in published maps and institutional affiliations. 